\title{
"TAX SIMPLIFICATION"-GRAVE THREAT TO THE CHARITABLE CONTRIBUTION DEDUCTION: THE PROBLEM AND A PROPOSED SOLUTION
}

\author{
STANLEY S. WEITHORN*
}

The present National Administration has continued to support proposed legislative changes aimed at substantially reducing the number of income tax returns in which deductions are itemized. The author contends that these "tax simplification" proposals are incompatible with the preservation of the charitable contribution deduction and would undermine the position of voluntary charitable organizations by reducing the incentives for giving. He proposes a solution to this dilemma by promoting the charitable contribution deduction, with certain limitations, to the position of $a \cdot d e d u c t i o n$ from gross income, rather than a deduction from adjusted gross income.

HE PHRASE "tax simplification" has an appealing ring to payer and payee alike, particularly, from the point of view of the taxpayer, when it is accompanied by the possibility of a reduction in effective tax rates.' In an endeavor to capitalize upon this appeal, the present National Administration has continued to press, through both the executive and legislative branches, for statutory changes, purportedly designed to achieve true "tax simplification."1

\section{Benefits of "TAX Simplification"}

Why the great pressure to attain this goal? Probably the primary reason is its self-policing effect, which would relieve, at least partially, the crushing administrative burden now borne by the audit staff of the Internal Revenue Service. With newly installed automatic data-

* B.S. 1947, Hofstra University; LL.B. 1954, LL.M. 1956, New York University; Member New York Bar. Author, TAX TEchniques for Foundations aNd OtHer ExeMPT OrGANIZATIONS.

${ }^{1}$ E.g., President's Economic Message, 112 Cong. Rec. 1188, 1192 (daily ed. Jan. 27, 1966). See generally Bittker, An Optional Simplified Income Tax, 21 TAx L. REv. 1 (1965); Blum, Federal Income Tax Reform-Twenty Questions, 41 Taxes 672 (1963); Pechman, Erosion of the Individual Income Tax, 10 NAT. TAX J. 1 (1957). 
processing systems about to be utilized to verify the reporting of virtually all items of gross income (compensation, dividends, interests, rents, royalties, etc.), the problem of inadequate policing of the avalanche of individual and joint federal income tax returns filed annually centers upon the area of itemized deductions. Thus, if a statutory scheme designed to decrease substantially the number of returns in which deductions are itemized is enacted, many millions of returns can be shifted to the computer area for vertification and the IRS audit staff will be able to concentrate on business enterprise returns and on the reduced number of personal returns still containing itemized deductions.

\section{Effect of Tax Simplification on Charitable Organizations}

How would such a change in our tax law affect the charitable ${ }^{2}$ sector? This may be answered by a brief review of the most significant of the "tax simplification" proposals put forward within recent years.

\section{Kennedy Proposal}

The first of this group was termed "A Floor Under Itemized Deductions of Individuals" and was presented to the Congress as part of the late President Kennedy's 1963 Tax Message. ${ }^{3}$ Specifically, the President explained his proposal as follows:

Most taxpayers use the "standard deduction" generally equal to 10 percent of income up to a maximum of $\$ 1,000$. But ever since this standard deduction was introduced during World War II, the proportion of taxpayers using it has declined steadily. At present, more than 40 percent of all individual income tax returns are filed by people who itemize deductions for a variety of deductible personal expenses, such as State and local taxes, interest, charitable contributions, medical expenses, and casualty losses. The amount of itemized deductions claimed on tax returns has gone up sharply -from less than $\$ 6$ billion in 1942 to $\$ 25.7$ in 1957 and $\$ 40$ billion in 1962.

The present practice of allowing taxpayers to deduct certain expenses in full-the only exception being medical expenses which

\footnotetext{
${ }^{2}$ As used herein, the word "charitable" refers to the entire area of organizations which themselves are tax-exempt and contributions to which are tax-deductible. Thus, included therein are colleges and universities (as well as other types of educational organizations), health and welfare organizations, religious organizations, and the like. 8109 CoNG. Rec. 962 (1963).
} 
are subject to a 3 percent floor plus a 1 percent floor for drugsraises difficult problems of equity, taxpayer compliance, and tax administration and enforcement. One purpose of itemized deductions is to relieve those taxpayers who are burdened by certain expenses or hardships in unusually large amounts, such as those involved in heavy casualty losses or serious illness. Another purpose is to stimulate certain desirable activities, such as charitable contributions or homeownership. Where such outlays are minimal relative to annual income, no serious hardship occurs and no special incentive is needed.

I, therefore, recommend that itemized deductions, which now average about 20 percent of adjusted gross income, be limited to those in excess of 5 percent of the taxpayer's adjusted gross income. This 5 percent floor will make $\$ 2.3$ billion of revenue available for reduction in individual tax rates. At the same time incentives to homeownership or charitable contributions will remain. In fact, this tax program as a whole, providing as it does substantial reductions in Federal tax liabilities for virtually all families and individuals, will make it easier for people to meet their personal and civic obligations.

This broadening of the tax base which permits a greater reduction in individual income tax rates has an accompanying advantage of real simplification. An additional 6.5 million taxpayers will no longer itemize their deductions but still benefit overall from the reduced rates and other relief measures.*

Thus, under this approach, the annual "package" of expenditures in those areas subject to itemization would be deductible only to the extent that it exceeds $\mathbf{5}$ percent of adjusted gross income. For example, a person with $\$ 20,000$ of adjusted gross income and $\$ 4,000$ in expenditures for local taxes, contributions, etc., can now deduct the entire $\$ 4,000$. Had the Administration's proposal been enacted, his total deductions would be limited to only $\$ 3,000$ since the first $\$ 1,000$ (5 percent of his $\$ 20,000$ adjusted gross income) would not be deductible. In a recent year, the average taxpayer who itemized deductions took 5.8 percent of adjusted gross income on account of local and state taxes, 4.6 percent on account of interest, 3.8 percent on account of contributions, 2.9 percent on account of medical expenses and 2.4 percent on account of other deductible expenses for a total of 19.5 percent of adjusted gross income. ${ }^{5}$

Id. at 967 .

- United States Treasury Dept., 1962 Statistics of INCOME: Individual INCOME TAX RETURNS 5 (1965). 
Potential Impact of Kennedy Proposal

One of the stated purposes of the proposal was to encourage greater use of the standard deduction, ${ }^{\mathrm{B}}$ which it certainly would have accomplished. This may be illustrated by the case of a taxpayer having $\$ 15,000$ of adjusted gross income and a deductible package of $\$ 1,300$. Since $\$ 750$ (5 percent of $\$ 15,000$ ) of these could not be deducted, the taxpayer would face the choice of using the standard deduction of $\$ 1,000$ or only $\$ 550$, the difference between $\$ 1,300$ and $\$ 750$. Obviously, he would take the standard deduction. It is apparent that there are no incentives for making charitable contributions inherent in the standard deduction since that deduction may be taken whether or not the taxpaper has made any contributions.

It is the universal experience of a wide variety of charitable organizations that large givers to whom tax deductibility is an important consideration are influenced significantly by the "net cost" of their gifts after taxes. ${ }^{7}$ Further, it is incorrect to assume that taxes are not a factor even for middle-income contributors in determining whether and to what extent they will contribute to charitable causes. It is therefore apparent that all charitable organizations depend for important support on middle and upper management people, individuals of substantial personal wealth, professional people, and self-employed individuals. The degree of dependence varies according to the particular characteristics and fund-raising methods of the organizations. In some cases these people are the sole source of support, while in other cases their gifts may represent only a part of the total contributions received by the organization. Even in the latter case, however, they represent the difference between being able to implement a fully effective program and not being able to do so.

Thus, evaluation of the " $5 \%$ floor" approach, in 1963, indicated that the eventual consequences of this Administration-sponsored legislative proposal would have been to make it more difficult to secure support for charitable organizations, would have reduced incentives for giving, and would have undermined the position of

\footnotetext{
- INT. REv. CODE OF 1954, § 141.

'See Sugarman, Charitable Giving Developments in Tax Planning and Policy, 39 TAXEs 1027, 1028-29 (1961); note 17 infra and accompanying text; cf. Merritt, The Tax Incentives for Lifetime Gifts to Charity, 39 TAXES 104 (1961).
} 
voluntary educational, health, welfare, religious, and cultural organizations in relation to government. Although the Administration obviously had no intention of bringing about such a result, it seems clear that this would have been the effect.

Based upon evaluations such as the one set forth above, a substantial number of the organizations that would have been affected by the enactment of the 1963 " $5 \%$ floor" proposal expressed their views to the Congress (in the form of public testimony, private correspondence and conferences, and the like), and as a consequence the proposal was deleted from what eventually was enacted as The Revenue Act of $1964 .^{8}$

\section{Long Proposal}

Senator Russell B. Long of Louisiana, Chairman of the Senate Finance Committee, has reintroduced, on a number of occasions since the end of 1963, a bill for a "simplified tax system." The two salient features of this bill are as follows:

1. Increase the maximum limitation on the standard deduction from $\$ 1,000$ or 10 percent of adjusted gross income, whichever is less, to $\$ 2,000$ or 10 percent of adjusted gross income, whichever is less.

2. Permit taxpayers to choose between two methods of calculating their tax:

(a) use of current tax rates after decreasing gross income by the aggregate of all the exemptions, deductions, and exclusions to which they are entitled; or

(b) use of new lower tax rates in respect of adjusted gross income (i.e., virtually all income, including capital gains), without benefit of most deductions (e.g., charitable contributions) and exclusions. Taxpayers choosing this method would be required to continue to use it for 5 years. However, they could revert to the other method (i.e., the present system) whenever they wished, provided that they recalculated their tax for the years during which the so-called simplified method had been in use and paid any additional taxes shown to be due for such years plus a 5 percent penalty and accrued interest.

\footnotetext{
78 Stat. 19.

${ }^{\circ} 109$ Cong. Rec. 19,706 (1963) (amendment to Revenue Act of 1964 offered by Senator Long); S. 3250, 88th Cong., 2d Sess. (1964); S. 2780, 89th Cong., 2d Sess. (1966).
} 
Senator Long has estimated that approximately 2.8 million taxpayers would take advantage of the two above-described alternatives offered under his proposal, about 2.5 million would benefit from the increase in the standard deduction ceiling, and about 313,000 would benefit from the use of the optional method of computing their tax. ${ }^{10}$

Over 1.8 million of those who would benefit from the increase in the standard deduction ceiling already use the present standard deduction despite its lower ceiling. ${ }^{11}$ lt is estimated that their number would be swelled by an additional 664,000 taxpayers if the ceiling were raised as Senator Long proposes. ${ }^{12}$ This latter group now itemize their deductions. Ninety-nine percent of these 2.5 million taxpayers have adjusted gross incomes in excess of $\$ 10,000 .^{13}$ Of the estimated 313,000 taxpayers who would benefit from the optional method of calculating their tax, 240,000 have adjusted gross incomes of between $\$ 20,000$ and $\$ 50,000$, and 63,000 have adjusted gross incomes exceeding $\$ 50,000 . .^{14}$

The removal of tax incentives for charitable giving from so many in these strategic groups would have serious consequences for publicly-supported charitable organizations, since it would place in jeopardy a substantial portion of the $\$ 7.5$ billion deducted in 1962 by taxpayers who itemized their contributions to colleges, churches, hospitals, and other charitable organizations. ${ }^{15}$

\section{Potential Impact of the Long Proposal}

Increased Standard Deduction Ceiling. There are no tax incentives for charitable giving for those who use the standard deduction. As noted above, it is estimated that 664,000 taxpayers with adjusted gross income between $\$ 10,000$ and $\$ 50,000$ who now itemize their deductible expenses would use the standard deduction if this feature of the proposal were enacted. ${ }^{16}$ These people give approximately $\$ 300$ million annually to colleges, churches, and other

10110 Cong. Rec. 23,662 (1964) (Tables 5, 6, and 7).

11 Id. Table 6.

12 Id. Tables 6 and 7.

18 See Id. Table 5 .

14 Id. Tables 6 and 7 .

${ }^{5}$ United States Treasury Dept., 1962 Statistics of Income: Individual Income TAX RETURNS 6-7 (1965).

${ }^{20}$ See note 12 supra and accompanying text. 
charities. ${ }^{17}$ The people in this income category are among the "new philanthropists" whose giving has been especially cultivated in recent years by the colleges and the United Funds and Community Chests. While it is true that they give for a variety of reasons, the experience of fund raisers is that tax deductibility is a factor of growing importance to them, not only in determining whether to give, but, more importantly, in establishing the level of their generosity. ${ }^{18}$

Optional Method. The proposed elective system of calculating income tax for use by people with higher incomes could have a serious negative impact on charitable giving and generosity. It is estimated that some 60,000 taxpayers with adjusted gross incomes in excess of $\$ 50,000$ would avail themselves of this option. ${ }^{19}$ This is over 40 percent of the 143,000 taxpayers in this income category who now report deductible charitable contributions in excess of $\$ 800$ million. ${ }^{20}$

From the standpoint of charitable giving, the impact may be twofold-on the amount given and on the strategy of fund raising through which contributions are secured. As to the amount given, those who elected the optional method would have no tax incentive for charitable giving. These are people who are particularly conscious of the after-tax cost of a charitable gift, and thus deductibility is a major factor in determining the amount of their support. These are the givers who are counted on for leadership gifts, and to the extent that the removal of the tax incentive reduced their giving, it would also affect the level of response of all other contributors to the particular cause.

As to the effect on fund-raising strategy, the fund-raising methods in general use today require timely leadership to give the campaign organization the momentum required to carry it to its objective within the limited time during which the attention and interest of prospective contributors can be held. When the gift is received is as important as its size in many cases. The fact that many contributors in this income category now tend to postpone their decisions until they can determine their year-end tax situation is a

\footnotetext{
17 See United States Treasury Depr., 1962 Statistics of Income: Individual Income TAX RETURNS 6 (1965).

${ }^{18} \mathrm{Cf}$. Sugarman, supra note 7 , at $1030-32$; text accompanying note 7 supra.

10 110 Cong. REc. 23,662 (1964) (Table 6).

${ }^{20} 1965$ Statistical Abstract of the United States 405 (86th ed.).
} 
genuine handicap to fund-raising organizations. The optional method would greatly magnify and compound this difficulty.

First of all, taxpayers would tend to postpone consideration of substantial gifts until they could determine which method of computing their tax to use. If they decided to elect the regular method, they would make their decisions about giving without the feeling of urgency which may have existed months earlier in the heat of the fund-raising effort, a result which would tend to lower the level of their gifts. If, at year-end, they chose the optional method, they would have no tax incentives for giving at all. Further, for each year that the election was in force, there would be no tax incentive to contribute, even at year-end. If they subsequently "dis-elected," the retroactive recomputation of tax liability would not provide for the retroactive making of charitable contributions for such prior years, and as many as five years could be involved.

No matter which method is used, the consequent effect will be to reduce the support of voluntary educational, charitable, religious, and cultural activities. This proposal is still very much "alive" and, in fact, the recommended solution set forth later herein was developed originally by the author in connection with the Long proposal.

\section{Other Proposals}

In a December, 1965, article entitled, interestingly, Good News For Taxpayers, Representative Wilbur D. Mills of Arkansas, Chairman of the House Ways and Means Committee, called for simplification of the tax laws. ${ }^{21}$ In the area of itemized deductions he set forth three alternative plans. One plan would increase the standard deduction..$^{22}$ A second plan would reduce tax rates by approximately 10 percent, or perhaps more in the upper brackets, for those willing to forego the standard deduction or itemized deductions. ${ }^{23}$ A third plan would reduce the rates by 10 . percent, and even more in the upper ranges, and then allow (1) no standard deduction and (2) itemized deductions only above a 10 percent of adjusted gross income floor. ${ }^{24} \mathrm{Mr}$. Mills has called upon Congress and the Treas-

21 Mills, Good News for Taxpayers, Nation's Bus., Dec. 1965, at 50.

22 Id. at 96.

${ }^{23} \mathrm{Id}$.

24 Id. 
ury Department to explore these various suggestions and the exploration is now underway. ${ }^{25}$

President Johnson in his 1966 Economic Report stressed the same theme, stating: ". . . improvement of our tax system is a continuing need which will concern this Administration and which deserves the support of all Americans .... . One major goal must be simplification of the tax law." 26 Thus, the charitable contribution deduction finds itself continually in the position of an unwilling combatant, and those defending it are called upon to fight what really are other people's battles. Before proposing a possible solution to this dilemma, a brief look at the history and status of the charitable contribution deduction is in order.

\section{Historical Background of Charitable Contribution Deduction}

Proposals to place further limitations on contribution deductibility are steps away from the historic position which government has hitherto taken in relation to voluntary charitable, educational, religious, and cultural organizations. From the earliest days of the Nation, our federal and state governments have adhered consistently to the principle of tax exemption for charitable organizations. ${ }^{27}$ Contribution deductibility is an inherent aspect of tax exemption.

The concept of governmental assistance to charitable organizations through tax exemption originated in the Middle Ages and the famous Statute of Charitable Uses in England.28 The American colonists brought this tradition with them and incorporated it in the laws of the various states. ${ }^{29}$ Even where no specific exempting legislation was passed, custom and common understanding dictated the practice of tax exemption for charitable organizations. In fact:

[b]y 1894 the practice of granting tax exemptions in favor of religious, educational and charitable institutions was virtually universal among the American states. Sometimes such exemption was granted by the State constitution, sometimes by general statute, sometimes by special act. Sometimes, also, the tax exemption was granted in the charter of the institution-and such charter exemp-

${ }^{25}$ See id.

${ }^{20} 112$ Cong. Rec. 1192 (daily ed. Jan. 27, 1966).

${ }^{27}$ E.g., An Act for the Direction of Listers in Their Office and Duty, [1769] Acts \& Laws of Conn. 135, 138; Of the Assessment and Collection of Taxes, 1 N.Y. REv. STAT. 388 (1828); see text accompanying note 29 infra.

2843 Eliz. I, ch. 4 (1601).

20 See note 27 supra and accompanying text. 
tions were held by the Supreme Court of the United States to be contractual in nature, and thus within the constitutional prohibition against the impairment of contracts by States. ${ }^{30}$

The first federal corporate income tax was imposed during the Civil War, but only on certain types of corporations. ${ }^{31}$ In 1894 Congress enacted the first law which taxed the income of corporations generally, ${ }^{32}$ and in doing so it specifically exempted charitable organizations. $^{33}$ A similar exemption has appeared in every federal income tax law since, including the Revenue Act of $1913^{34}$ which was adopted after the sixteenth amendment was added to the Constitution. ${ }^{35}$

The charitable contribution deduction was first enacted in 1917,30 almost simultaneously with the imposition of the income tax. ${ }^{37}$ It applied to individuals only, and was limited to 15 percent of income. In 1935, however, deductibility was extended to corporate contributions. ${ }^{38}$ The evidence is overwhelming in the records of the congressional hearings that the underlying policy which impelled the adoption of contribution deductibility was identical with that which had historically inspired tax exemption. ${ }^{39}$

It is clear that "[a]ll of these provisions help charitable organizations either directly, by relieving them from the burdens of taxation, or indirectly by stimulating potential contributors to generosity." 40 Yet legislators and courts are consistent in their position

\footnotetext{
so Federal Income Tax Exemption of Charitable Organizations (unpublished study prepared for Rockefeller Foundation, 1954).

${ }^{32}$ Act of July 1, 1862, ch. 119, 12 Stat. 468 (e.g., railroad, steamboat, ferry, and insurance corporations).

${ }^{82}$ Act of August 27, 1894, ch. 349, 28 Stat. 509.

ss Id. $\$ 32$.

st Act of October 3, 1913, ch. 16, §II (G) (a), 38 Stat. 172.

ss U.S. CoNST. amend. XVI: "The Congress shall have power to lay and collect taxes on incomes, from whatever source derived, without apportionment among the several States, and without regard to any census or enumeration." Formal certification of ratification was made on February $25,1918$.

${ }^{30}$ Act of October 3, 1917, ch. 68, §1201 (2), 40 Stat. 330.

s7 Prior to that time, government at all levels was financed primarily by custom duties, excise, and property taxes, so that it was unnecessary to provide for contribution deductibility.

${ }^{38}$ Revenue Act of 1935, ch. 829, § 102 (c), 49 Stat. 1016 (now INT. REv. Code of 1954, $\S 170)$.

so See Hearings on H.R. 8974 Before the Comm. on Ways and Means, 74th Cung., 1st Sess. 115-24 (1935); S. REP. No. 1240, 74th Cong., 1st Sess. (1935); H.R. REP. No. 1681, 74th Cong., 1st Sess. (1935); H.R. REP. No. 172, 65th Cong., 1st Sess. (1917).

${ }^{\circ}$ Federal Income Tax Exemption of Charitable Organizations (unpublished study prepared for Rockefeller Foundation, 1954).
} 
that the concept of tax exemption is justified by the saving of expenses to the government resulting from the operations of charitable organizations.11 While this has obvious practical appeal, "it is easy to demonstrate that not mercenary advantage to the government but a higher regard for public benefit has been the controlling motive of the law-makers." 42

\section{Uniqueness of the Chapitable Contribution Deduction}

There is great danger to the whole philanthropic enterprise in efforts to curtail itemized deductions. There is a tendency to think of the various items of deductible expense as being all of one kind. Indeed, some people refer to all of them indiscriminately as "tax loop-holes." In the face of a tendency to advocate sweeping changes in this feature of the income tax law, there is need for legislators and others to recognize both the uniqueness of charitable contributions and their historic philosophic and practical significance.

The uniqueness of the charitable contribution deduction lies in the fact that a gift to a publicly-supported educational, religious, charitable, or cultural organization is essentially an act of unselfishness and generosity. It is discretionary. It is an expenditure in the public interest. No other deductible expense has all these characteristics, and few have any of them.

It must also be recognized that the contribution deduction feature is the primary means by which the federal government encourages and assists charitable organizations, ${ }^{43}$ thereby demonstrating its support of the pluralistic approach to meeting social needs. This method of helping charitable organizations has the added advantage of permitting a wide variety of voluntary educational and charitable activities to take place under diverse religious and other sponsorship without the kind of federal intrusion that could result from other methods of government assistance. Finally, government itself is a major beneficiary of the activities of the voluntary groups that depend on tax deductible contributions, since much of the work they do would require direct government financing if it were not done voluntarily.44

"1 See, eg., H.R. Rer. No. I860, 75th Cong., 3d Sess. 19 (1938); St. Louis Union Trust Co. v. United States, 374 F.2d 427, 432 (8th Cir. 1967); People ex rel. Holland Coal Co. v. Isaacs, 22 Ill. 2d 477, 483, I'j6 N.E.2d 889, 892 (1961).

12 Federal Income Tax Exemption of Charitable Organizations (unpublished study prepared for Rockefeller Foundation, 1954).

"s See also INT. REv. CODE of 1954, §501.

"See note 41 supra and accompanying text. 
The Proposed Solution

All that has gone before makes it clear that, under the Internal Revenue Code in its present form, "tax simplification" is incompatible with the preservation of the charitable contribution deduction. Thus, those interested in retaining contribution deductibility have been forced to oppose the above-noted proposals even though they may, in fact, be otherwise sympathetic with the concept of tax simplification.

The resolution of this dilemma thus would appear to lie in the removal of the contribution deduction, at least partially, from the embattled position in which all itemized deductions now seem to be. This could be accomplished rather simply by "promoting" the contribution deduction, with certain limitations, to the position of a deduction from gross income, under section 62 of the Internal Revenue Code, ${ }^{45}$ rather than a deduction from adjusted gross income. Section 62 would be amended by the designation of a new paragraph 9 to read:

\section{Sec. 62. ADJUSTED GROSS INCOME DEFINED.}

For purposes of this subtitle, the term "adjusted gross income," means in the case of an individual, gross income minus the following deductions: ....

(9) Contributions.--In the case of a charitable contribution by an individual to an organization described in section $170(\mathrm{~b})(1)$ (A), payment of which is made within the taxable year, the deduction allowed by section 170 . However, the deduction available under this paragraph shall be limited to the amount by which the total deduction allowed by section 170 in respect of all charitable contributions exceeds 2 percent of the adjusted gross income as computed without reference to this paragraph.

These comments regarding the suggested wording may be helpful:

1. The reference to "individual" is self-evident, since the concept of "adjusted gross income" is geared to the individual taxpayer. ${ }^{46}$

2. The reference to an "organization described in section 170 (b) (1) (A)" is to that class of organizations described which now qualifies

¿5 INT. REV. Code of 1954, § 62.

"Id. 
for the extra 10 percent, that is, schools, churches, hospitals, and other publicly-supported organizations, but excluding private foundations. 47

3. The reference to "payment ... . within the taxable year" is basic to deductibility, in any event.

4. The reference to "deduction allowed by section 170" is intended to avoid repetition of substantial amounts of statutory language and to correlate this provision with the basic statute.

5. The entire second sentence is intended to limit this provision to the deduction of extraordinary charitable contributions. Whether or not 2 percent of adjusted gross income represents a proper line of demarcation is a secondary consideration, the real aim of this limitation being to enlist the support of the Administration by making the proposed amendment inapplicable to personal tax returns which would not otherwise be likely candidates for audit by the Internal Revenue Service because the standard deduction is used. Without this special limitation, virtually every tax return filed would include itemization which, of course, would be totally unacceptable to the Government. However, the concept of the extraordinary charitable contribution being deductible hereunder, with the basic 2 percent still being available for possible itemization in the usual manner, represents a reasonable compromise.

This simple legislative proposal thus would isolate and preserve the extraordinary contribution to a publicly-supported charitable organization from any future statutory changes aimed at modifying the basic concept of itemized deductions. That is so, as explained above, ${ }^{48}$ because this amount then would be deductible from gross income rather than from adjusted gross income, and deductions from gross income do not stand in a position of vulnerability. The accomplishment of this simple and modest change in the Internal Revenue Code would therefore free the energies of those individuals who have been called upon to fight the battle for the preservation of itemized deductions for far more productive and rewarding work within the charitable sector of our national life.

\footnotetext{
17 INT. Rev. CODE OF 1954, \$170 (b) (1) (A).

${ }^{4}$ See note 45 supra and accompanying text.
} 